\title{
Plasma Immunoreactive Endothelin-1 Concentration in Human Fetal Blood: Its Relation to Asphyxia
}

\author{
YUKA ISOZAKI-FUKUDA, TAKATSUGU KOJIMA, YUKIO HIRATA, ATSUSHI ONO, \\ SUSUMU SAWARAGI, ISAMU SAWARAGI, AND YOHNOSUKE KOBAYASHI \\ Departments of Pediatrics [Y.I-F., T.K., A.O., Y.K.] and Obstetrics and Gynecology [S.S., I.S.], Kansai Medical \\ University, Fumizonocho 1, Moriguchi, Osaka 570, Japan and 2nd Department of Internal Medicine, Tokyo \\ Medical and Dental University, School of Medicine, Yushima, Bunkyoku, Tokyo 113, Japan [Y.H.]
}

\begin{abstract}
To elucidate the effects of birth stress on immunoreactive endothelin-1 (irET-1) concentrations in fetal blood, we determined irET-1 levels in cord plasma in different modes of delivery associated with or without complications such as asphyxia. The irET-1 concentrations in both the umbilical artery and vein were significantly higher than those found in maternal venous blood at delivery, although there was no significant difference between preterm and full-term infants. When plasma irET-1 concentrations of healthy infants born by vaginal delivery and by cesarean section without labor were compared, the former had significantly $(p<0.05)$ higher levels than the latter $(15.4 \pm 4.9 \mathrm{pg} / \mathrm{mL}$ versus $11.1 \pm 3.1 \mathrm{pg} / \mathrm{mL})$. Furthermore, umbilical venous plasma obtained from vaginally delivered infants complicated by asphyxia showed significantly $(p<0.001)$ higher irET-1 levels $(28.2 \pm 9.4 \mathrm{pg} /$ $\mathrm{mL})$ than those of nonasphyxiated infants $(14.2 \pm 4.5 \mathrm{pg} /$ $\mathrm{mL}$ ). These data suggest that birth stress, especially asphyxia, may contribute to the increase in fetal circulating irET-1 levels. (Pediatr Res 30: 244-247, 1991)
\end{abstract}

\section{Abbreviations}

CPK, creatine phosphokinase

ET-1, endothelin-1

GOT, aspartate aminotransferase

irET-1, immunoreactive ET-1

LDH, lactic acid dehydrogenase

TFA, trifluoroacetic acid

Endothelin-1 is a potent vasoconstrictor peptide with 21 amino acid residues, originally isolated and sequenced from the supernatant of cultured porcine aortic endothelial cells, and the first member of the mammalian endothelin family (1-4). Since ET1 produces very potent vasoconstriction and an extremely longlasting pressor response, ET-1 may play an important role in the control of blood pressure and/or local blood flow $(1,3,4)$. Recently, low concentrations of ET-1 have been detected in plasma from healthy subjects (5-7). Raised plasma concentrations of ET-1 have been observed in certain pathophysiologic conditions, such as uremia (8), acute renal failure (9), acute

Received September 18, 1990; accepted April 26, 1991.

Correspondence: Yuka Isozaki-Fukuda MD. Department of Pediatrics, Kansai Medical University, Fumizonocho 1, Moriguchi, Osaka 570, Japan.

Supported in part by research grants from the Morinaga Hoshikai, The Mami Mizutani Foundation and Katanosho (1988) of Kansai Medical University, Uehara Memorial Foundation and research grants from the Ministry of Education, Science, and Culture. myocardial infarction (10), cardiogenic shock (11), major surgery (12), and subarachnoid hemorrhage (13). Furthermore, high levels of circulating ET-1 in fetal blood have recently been reported and the possible physiologic role(s) of ET-1 at delivery has been investigated $(14,15)$. However, it remains unknown whether ET-1 levels in the umbilical cord plasma may change under physiologic and pathophysiologic states during delivery. This study was undertaken to elucidate the effects of birth stress, especially asphyxia, on ET-1 concentrations in the human umbilical cord plasma.

\section{SUBJECTS AND METHODS}

Subjects. Thirty-five neonates ( 20 boys and 15 girls) consisting of 14 preterm and 21 full-term infants, and 10 mothers with no complications from delivery, were the subjects of this study. Informed consent was obtained from each infant's parents and the pregnant women before delivery. Gestational age, birth wt, Apgar score of $1 \mathrm{~min}$, and the mode of delivery of the subjects are shown in Table 1. Cesarean section procedure was chosen in some cases because of the narrow pelvis of some of the pregnant women. For lumbar anesthesia, procaine was used in all cases. There were no significant changes in maternal heart rate, blood pressure, or fetal distress during the lumbar anesthesia.

Blood sampling and extraction. Cord blood was drawn just after birth from the cord artery and vein. Maternal venous blood samples were obtained during delivery. Blood samples were collected into tubes containing EDTA, and centrifuged at 3000 rpm for $10 \mathrm{~min}$ at $4^{\circ} \mathrm{C}$. Plasma samples were stored at $-80^{\circ} \mathrm{C}$ until assayed.

Plasma samples were extracted as described previously (5) with some modifications. Amprep C2 mini-columns (Amersham Japan, Tokyo) were equilibrated by washing with $2 \mathrm{~mL}$ methanol, followed by $2 \mathrm{~mL}$ deionized water and $5 \mathrm{~mL} 0.1 \%$ (TFA). Plasma was acidified by the addition of $2 \mathrm{M} \mathrm{HCl}$, centrifuged at 3000 $\mathrm{rpm}$ for $10 \mathrm{~min}$ at $4^{\circ} \mathrm{C}$, and loaded onto the column. After washing with $5 \mathrm{~mL}$ deionized water $/ 0.1 \%$ TFA, the materials adsorbed to the column were eluted with $2 \mathrm{~mL} 0.1 \%$ TFA/ $80 \%$ methanol. The extracts were evaporated under a stream of nitrogen. The mean recovery of standards ET-1 from plasma was 61 $\pm 3 \%(n=4)$ after the extraction procedure.

$R I A$ of ET-1. ET-1 RIA was performed essentially in the same manner as reported (5) using a new polyclonal antibody specific for ET-1 (16). Samples were reconstituted with the assay buffer (50 mM phosphate buffer, $\mathrm{pH} 6.8$, containing $0.9 \% \mathrm{NaCl}, 1 \mathrm{mM}$ EDTA, $0.005 \%$ Triton X-100, $0.05 \% \mathrm{NaN}_{3}$ and $0.3 \%$ bovine $\gamma-$ globulin). Each 0.1-mL sample or standard ET-1 (Peptide Institute, Inc., Osaka, Japan) and 0.05-mL rabbit anti-ET-1 serum (final dilution: 1:30000) was preincubated at $4^{\circ} \mathrm{C}$ for $48 \mathrm{~h}$, followed by the addition of $0.05 \mathrm{~mL}{ }^{125} \mathrm{I}-\mathrm{ET}-1$ (Amersham Inter- 
national plc, UK). After $24 \mathrm{~h}$ incubation, the bound from free ligand was separated by the double antibody/polyethylene glycol method (5). The minimum detectable quantity in the present ET-1 RIA was $0.3 \mathrm{pg} /$ tube, and the $50 \%$ intercept was $9 \mathrm{pg} /$ tube. The antibody was specific for ET-1 because it crossreacted $100 \%$ with ET-1, but less than $0.01 \%$ with ET-2 and ET-3, and $1 \%$ with human big ET-1 and porcine big ET-1, respectively, on a molar basis (16). The intra- and interassay coefficients of variance were both less than $10 \%$.

Blood gas analysis and measurements of serum enzymes. The cord venous and arterial blood samples from all the asphyxiated infants were analyzed for blood gas using a Corning Blood Gas Analyzer (178 Corning Specific Instrument, Medford, MA) at $37^{\circ} \mathrm{C}$. Serum levels of lactic acid dehydrogenase (LDH), creatine phosphokinase (CPK) and aspartate aminotransferase (GOT) in the asphyxiated infants just after birth were measured by an Autoanalyzer (Beckman Astra-8, Beckman, Instruments, Inc., Fullerton, CA).

Statistical analysis. Data were expressed as the mean $\pm \mathrm{SD}$. Statistical analysis was performed using Student's $t$ test for unpaired data and paired $t$ test for paired data. $p$ values less than 0.05 were considered statistically significant.

\section{RESULTS}

Plasma irET-1 concentrations obtained simultaneously from the umbilical artery and vein from eight full-term healthy infants were $13.5 \pm 3.1 \mathrm{pg} / \mathrm{mL}$ and $15.8 \pm 4.4 \mathrm{pg} / \mathrm{mL}$, respectively; they were far greater than those of the unpaired maternal vein $(3.0 \pm$ $1.9 \mathrm{pg} / \mathrm{mL}$ ) obtained during normal vaginal delivery (Fig. $1 A, p$ $<0.001$ ). Two paired fetal and maternal irET-1 levels simultaneously obtained just after birth were 11.6 versus $2.6 \mathrm{pg} / \mathrm{mL}$ and 12.4 versus $3.5 \mathrm{pg} / \mathrm{mL}$, respectively. There was no significant difference in cord venous plasma irET-1 concentrations between healthy preterm and full-term infants born vaginally (Fig. $1 B$ ).

Cord venous plasma irET-1 concentrations, blood $\mathrm{pH}$, and base deficit in preterm and full-term infants born without complications by vaginal delivery and those by cesarean section were compared (Table 2). Plasma irET-1 levels in infants born vaginally were significantly $(p<0.05)$ higher than those in infants delivered by cesarean section without labor, whereas the former group had a significantly lower blood $\mathrm{pH}$ and a larger base deficit than the latter group.

The arterial blood gas in vaginally delivered infants with asphyxia (1-min Apgar score $\leq 6)$ showed a remarkably reduced $\mathrm{pH}(7.04 \pm 0.1)$ and a great base deficit $(11.6 \pm 6.3 \mathrm{mEq} / \mathrm{L})$. The asphyxiated infants had elevated serum levels of LDH $(1428.8 \pm 573.3 \mathrm{IU} / \mathrm{L}), \mathrm{CPK}(1224.5 \pm 82.8 \mathrm{IU} / \mathrm{L})$, and GOPT

Table 1. Clinical characteristics of infants examined in this

\begin{tabular}{|c|c|c|}
\hline No. $(\mathrm{M} / \mathrm{F})$ & $\begin{array}{c}\text { Preterm } \\
n=14(10 / 4)\end{array}$ & $\begin{array}{c}\text { Full-term } \\
n=21(10 / 11)\end{array}$ \\
\hline Gestational age (wk) & $\begin{array}{c}32.0 \pm 2.7 \\
(28-36)\end{array}$ & $\begin{array}{c}38.9 \pm 1.1 \\
(37-41)\end{array}$ \\
\hline Birth wt (g) & $\begin{array}{l}1865 \pm 737 \\
(800-3200)\end{array}$ & $\begin{array}{l}3.562 \pm 889 \\
(2900-4870)\end{array}$ \\
\hline 1-min Apgar score & $\begin{array}{c}6.8 \pm 1.8 \\
(3-9)\end{array}$ & $\begin{array}{c}8.0 \pm 1.5 \\
(4-10)\end{array}$ \\
\hline $\begin{array}{l}\text { Neonatal asphyxia (1-min Apgar } \\
\text { score } \leq 6)\end{array}$ & 7 & 3 \\
\hline \multicolumn{3}{|l|}{ Mode of delivery } \\
\hline \multicolumn{3}{|l|}{ Vaginal delivery } \\
\hline Nonasphyxia & 5 & 12 \\
\hline Asphyxia & 3 & 3 \\
\hline \multicolumn{3}{|l|}{ Cesarean section } \\
\hline Nonasphyxia & 3 & 5 \\
\hline Asphyxia & 3 & 1 \\
\hline
\end{tabular}

* Data are presented as mean $\pm \mathrm{SD}$.
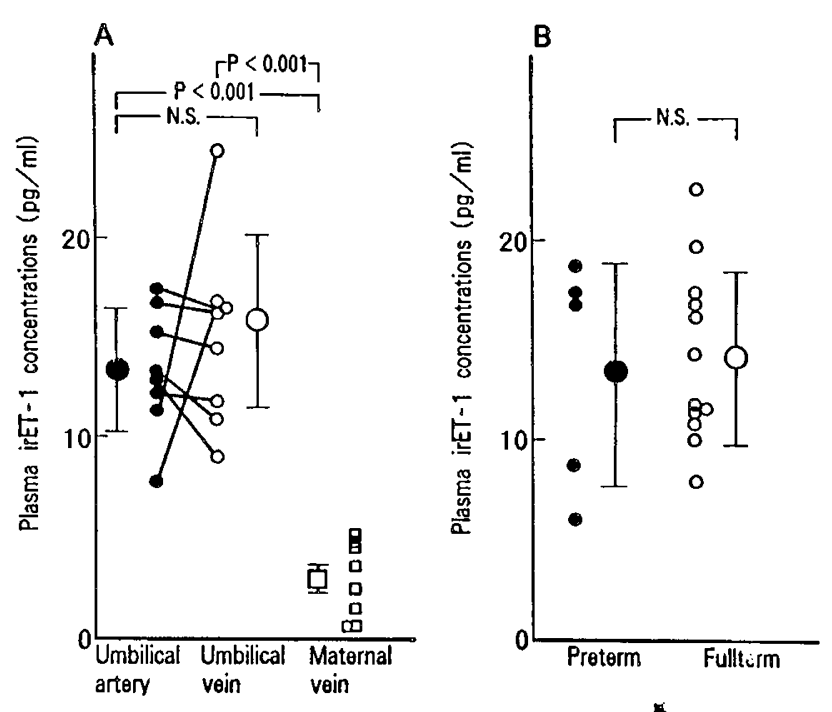

Fig. 1. irET-1 concentrations of $(A)$ umbilical artery $(\bullet)$, vein $(O)$, and maternal peripheral vein $(\square)$, and of $(B)$ umbilical venous blood in preterm $(\bullet)$ and full-term $(O)$ infants. Bars show SD. N.S., not significant $(p>0.05)$.

Table 2. Plasma irET-1, pH, and base deficit in umbilical venous blood in healthy infants delivered vaginally and by Cesarean section*

\begin{tabular}{lccc}
\hline & $\begin{array}{c}\text { Vaginal } \\
\text { delivery } \\
(n=17)\end{array}$ & $\begin{array}{c}\text { Cesarean } \\
\text { section } \\
(n=8)\end{array}$ & $\begin{array}{c}p \\
\text { value }\end{array}$ \\
\hline irET-1 $(\mathrm{pg} / \mathrm{mL})$ & $15.4 \pm 4.9$ & $11.1 \pm 3.1$ & $<0.05$ \\
$\mathrm{pH}$ & $7.28 \pm 0.05$ & $7.32 \pm 0.04$ & $<0.05$ \\
Base deficit (mmol/L) & $7.1 \pm 2.4$ & $3.2 \pm 1.4$ & $<0.01$ \\
\hline
\end{tabular}

* Data are expressed as mean \pm SD.

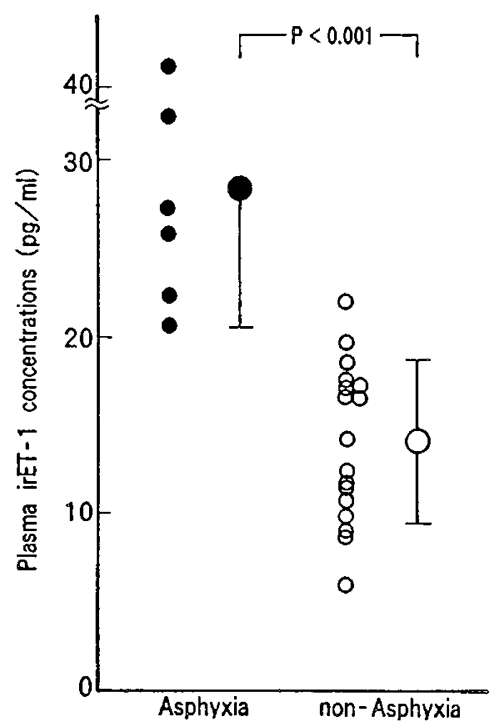

Fig. 2. irET-1 concentrations of the umbilical vein in infants with $(\bullet)$ or without $(O)$ asphyxia. Bars show SD. $p>0.05$, not significant.

$(76.3 \pm 29.7 \mathrm{IU} / \mathrm{L})$. As shown in Figure 2, plasma irET-1 concentrations in the asphyxiated infants $(28.2 \pm 7.5 \mathrm{pg} / \mathrm{mL})$ were significantly $(p<0.001)$ greater than those in the nonasphyxiated infants $(14.2 \pm 4.5 \mathrm{pg} / \mathrm{mL})$.

\section{DISCUSSION}

The present study clearly showed that plasma irET-1 concentrations in human fetal blood were remarkably higher than those 
in maternal blood, although there were neither significant differences in plasma irET-1 levels between umbilical cord artery and vein nor between preterm and full-term infants of uneventful vaginal delivery. Our data are consistent with those previously reported $(14,15)$. However, fetal plasma irET-1 concentrations in the present study were somewhat lower (14), but much greater (15), than those reported by others. The apparent discrepancy may be mainly due to the different assay systems, particularly different antibodies used in RIA. We have used specific ET-1 antibody, which does not show any crossreactivities with big ET1 or ET-3, both of which circulate in human blood $(10,17)$. Thus, cord plasma levels as determined in the present study should actually reflect circulating ET-1 in the fetal circulation.

Cord venous irET-1 levels in vaginally delivered infants were significantly higher than those in infants delivered by cesarean section without labor, although none of them were asphyxiated. When gas analysis of cord venous blood was compared between these infants, the vaginally delivered infants had lower $\mathrm{pH}$ and greater base deficit than those delivered by cesarean section. During labor, uterine contraction alters fetal oxygenation by reducing maternal placental blood flow (18), and a relative asphyxia is always present, mostly of a very short duration. Although we failed to examine the fetal arterial blood gas in this study, it appears that the infants born by uneventful vaginal delivery are more acidotic than those delivered by cesarean section without labor. Therefore, the reduced gas exchange through the placenta found in vaginally delivered infants is likely due to reduction of the placental blood flow by uterine contraction during labor, which may be responsible for the increased fetal ET-1 levels in the fetal circulation.

The present study further demonstrated that cord plasma irET1 concentrations in the asphyxiated infants as determined by 1 min Apgar score were significantly higher than those in the nonasphyxiated infants born by vaginal delivery. The asphyxiated infants in this study had severe hypoxia and acidosis associated with elevated serum LDH, CPK, and GOT levels (19, 20 ). These observations led us to suggest that the hypoxic and/ or acidotic conditions that occurred during vaginal delivery with labor may induce an increase in synthesis and/or secretion of ET-1 in the fetal circulation at birth. Recently, it has been reported that hypoxia directly stimulates ET-1 release from rat mesenteric arteries in vitro (21), and the experimental asphyxia also caused the increased plasma irET-1 levels in the pig (22). These observations lend strong support to our suggestion.

It seems likely that labor and vaginal delivery is more stressful to the fetus than cesarean section without labor, because compression of the head and body in the process of fetal descent and passage through the birth canal induce the release of stress hormones, such as catecholamines and arginine vasopressin, into the fetal circulation $(23,24)$. It should be noted that both adrenaline and vasopressin stimulate an induction of $\mathrm{mRNA}$ for ET-1 precursor and release of ET-1 from endothelial cells in vitro $(1,25)$. It seems unlikely, however that these stress hormones circulate in such extremely high concentrations as used in vitro, during delivery and asphyxia. Interestingly, a recent study demonstrated that human preproendothelin-1 gene contains hexanucleotide consensus sequences known as acute-phase reactant regulatory elements, which are thought to mediate the induction of gene expression under acute physical stress in vivo (26). Previous clinical observations have described that circulating irET-1 levels are transiently elevated after various physical stresses in man, including major surgery (12), acute myocardial infarction (10), subarachnoid hemorrhage (13), and acute renal failure (9). Therefore, it is reasonable to speculate that the fetus is vulnerable to the transient stress during labor and vaginal delivery by which the expression of ET-1 gene in vascular endothelium may be induced as an acute-phase reactant.

The main source of ET-1 in the fetal circulation could not be elucidated from the present study. The significantly higher levels of irET-1 in the fetal blood compared to those in maternal blood may reflect the fetal production of the peptide. Although active transport of ET-1 across the placenta could result in elevated fetal levels, the absence of its umbilical arterio-venous difference as reported by others (15) and by us argue against the possibility. However, we should consider the placenta to be a possible source for synthesis and secretion of ET-1 because the peptide was first cloned from a placental cDNA library (2).

It remains unclear what physiologic function(s) ET-1 has in the fetus during pregnancy and partus. It has been shown that human umbilical vessels constrict in response to exogenous ET1 in a dose-dependent manner with a threshold concentration of $100 \mathrm{pM}$ in vitro, which suggests the possible contribution of ET1 to the closure of human umbilical vessels at delivery (14). Plasma irET-1 concentrations in the fetal circulation as measured by RIA in the present study and others $(14,15)$ were estimated to be about 10 times less than those used to induce such pharmacologic effects. However, the local concentration of ET-1 should be much higher at the interface of the vascular endothelium and smooth muscle than that in the bloodstream. It would, therefore, be possible that endogenous ET-1 may act on the underlying vascular smooth muscle cells via the paracrine mechanism.

It is well recognized that hypoxia and acidemia during the fetal life lead to potent vasoconstriction and raised systemic blood pressure $(27,28)$. Thus, our observations of the increased circulating fetal irET-1 levels triggered possibly by birth stress and more profoundly by asphyxia suggest that endogenous ET-1 may play physiologic/pathophysiologic role(s) in redistribution of blood volume to vital organs and/or constriction of placental vessels that take place at the time of birth. Recent studies have further demonstrated the presence of specific ET-1 receptors in the human placenta $(29,30)$ and the pressor effects of ET-1 in the human fetoplacental cotyledon (29). Taken together, ET-1 may have some regulatory roles in maintaining the vascular tonus as well as blood flow in the fetoplacental circulation system at birth.

\section{REFERENCES}

1. Yanagisawa M, Kurihara $H$, Kimura S, Tomobe $Y$, Kobayashi M, Mitsui $Y$, Yazaki Y, Goto K, Masaki T 1988 A novel potent vasoconstrictor peptide produced by vascular endothelial cells. Nature 332:411-415

2. Itoh $Y$, Yanagisawa $M$, Ohkubo $S$, Kimura $C$, Kosaka T, Inoue $A$, Ishida $N$, Mitsui Y, Onda H, Fujino M, Masaki T 1988 Cloning and sequence analysis of cDNA encoding the precursor of a human endothelium-derived vasoconstrictor peptide, endothelin: identity of human and porcine endothelin. FEBS Lett 231:440-444

3. Inoue A, Yanagisawa M, Kimura S, Kasuya Y, Miyauchi T, Goto K, Masaki T 1989 The human endothelin family: three structurally and pharmacologically distinct isopeptides predicted by three separate genes. Proc Natl Acad Sci USA 86:2863-2867

4. Yanagisawa M, Inoue A, Ishikawa $T$, Kasuya $Y$, Kimura $S$, Kumagaye $S$ Nakajima K, Watanabe TX, Sakakibara S, Goto K, Masaki T 1988 Primary structure, synthesis, and biological activity of rat endothelin, an endotheliumderived vasoconstrictor peptide. Proc Natl Acad Sci USA 85:6964-6967

5. Ando K, Hirata Y, Shichiri M, Emori T, Marumo F 1989 Presence of immunoreactive endothelin in human plasma. FEBS Lett 245:164-166

6. Suzuki N, Matsumoto H, Kitada C, Masaki T, Fujino M 1989 A sensitive sandwich-enzyme immunoassay for human endothelin. J Immunol Methods 118:245-250

7. Hartter E, Woloszczuk W 1989 Radioimmunoassay of endothelin. Lancet 1:909

8. Koyama H, Nishizawa Y, Morii H, Tabata T, Inoue T, Yamaji T 1989 Plasma endothelin levels in patients with uremia. Lancet 1:991-992

9. Tomita K, Ujiie K, Nakanishi T, Tomura S, Matsuda O, Ando K, Shichiri M, Hirata Y, Marumo F 1989 Plasma endothelin levels in patients with acute renal failure. N Engl J Med 321:1127

10. Miyauchi T, Yanagisawa M, Tomizawa T, Sugishita Y, Suzuki N, Fujino M, Ajisaka R, Goto K, Masaki T 1989 Increased plasma concentrations of endothelin-1 and big endothelin- 1 in acute myocardial infarction. Lancet 2:53-54

11. Cernacek P, Stewart DJ 1989 Immunoreactive endothelin in human plasma: marked elevations in patients in cardiogenic shock. Biochem Biophys Res Commun 161:562-567

12. Hirata Y, Itoh K, Ando K, Endo M, Marumo F 1989 Plasma endothelin levels during surgery. N Engl J Med 321:1686

13. Masaoka H, Suzuki R, Hirata Y, Emori T, Marumo F, Hirakawa K 1989 Raised plasma endothelin in aneurysmal subarachnoid haemorrhage. Lancet 2:1402 
14. Haegerstrand A, Hemsen A, Gillis C, Larsson O, Lundberg JM 1989 Endothelin: presence in human umbilical vessels, high levels in fetal blood and potent constrictor effect. Acta Physiol Scand 137:541-542

15. Nakamura T, Kasai K, Komura S, Emoto T, Banba N, Ishikawa N, Shimoda S 1990 Immunoreactive endothelin concentration in maternal and fetal blood. Life Sci 46:1045-1050

16. Ando K, Hirata Y, Takei Y, Kawakami M, Marumo F 1991 Endothelin-1like immunoreactivity in human urine. Nephron 57:36-39

17. Suzuki N, Matsumoto H, Miyauchi T, Goto K, Masaki T, Tsuda M, Fujino M 1990 Endothelin-3 concentrations in human plasma: the increased concentrations in patients undergoing haemodialysis. Biochem Biophys Res Commun 169:809-815

18. Novy M, Thomas CL, Less MH 1975 Uterine contractility and regional blood flow responses to oxytocin and prostaglandin $\mathrm{E}_{2}$ in pregnant rhesus monkeys. Am J Obstet Gynecol 122:419-433

19. Koch G, Wendel H 1968 Adjustment of arterial blood gases and acid base balance in the normal newborn infant during the first week of life. Biol Neonate 12:136-161

20. Klaus MH, Fanaroff AA 1986 Care of High Risk Neonate. 3rd Ed. WB Saunders, Philadelphia, p 410

21. Rakugi H, Tabuchi Y, Nakamaru M, Nagano M, Higashimori K, Mikami H, Ogihara T, Suzuki N 1990 Evidence for endothelin-1 release from resistance vessels of rats in response to hypoxia. Biochem Biophys Res Commun 169:973-977
22. Pernow J, Hemsen A, Hallen A, Lundberg JM 1990 Release of endothelin-like immunoreactivity in relation to neuropeptide $Y$ and catecholamines during endotoxin shock and asphyxia in the pig. Acta Physiol Scand 140:311-322

23. Jones III CM, Greiss Jr FC 1982 The effect of labor on maternal and fetal circulating catecholamines. Am J Obstet Gynecol 144:149-153

24. Hadeed AJ, Leake RD, Weitzman RE, Fisher DA 1979 Possible mechanisms of high blood levels of vasopressin during the neonatal period. J Pediatr 94:805-808

25. Emori T, Hirata Y, Ohta K, Shichiri M, Marumo F 1989 Secretory mechanism of immunoreactive endothelin in cultured bovine endothelial cells. Biochem Biophys Res Commun 160:93-100

26. Inoue A, Yanagisawa M, Takuwa Y, Mitsui Y, Kobayashi M, Masaki T 1989 The human preproendothelin-1 gene. J Biol Chem 264:14954-14959

27. Behrman RE, Lees MH, Peterson EN, Lannoy CW, Seeds AE 1970 Distribution of the circulation in the normal and asphyxiated fetal primate. Am J Obstet Gynecol 108:956-969

28. Cohn HE, Sacks EJ, Heymann MA, Rudolph AM 1974 Cardiovascular responses to hypoxia and acidemia in fetal lambs. Am J Obstet Gynecol 120:817-824

29. Wilkes BM, Mento PF, Hollander AM, Maita ME, Sung S, Girardi EP 1990 Endothelin receptors in human placenta: relationship to vascular resistance and thromboxane release. Am J Physiol 258:E864-E870

30. Fischli W, Clozel M, Guilly C 1989 Specific receptors for endothelin on membranes from human placenta. Characterization and use in a binding assay. Life Sci 44:1429-1436 